\title{
Schoolcraft vs. Becoming Somebody: Competing Visions of Higher Education among Working-Class College Students
}

\author{
Allison L. Hurst
}

\begin{abstract}
By exploring the meanings working-class students attribute to college and academic success, this article uncovers important and surprising disjunctures between the official view of college as a pathway to social mobility and students' own needs and aspirations. While some working-class college students do use college as a "ticket out of the working class," others reject this view, arguing that the twin functions of college as educative and credentialing should be delinked. It is important for researchers, as well as educators and policymakers, to recognize that working-class college students are not homogenous with regard to occupational interests and expectations of social mobility.
\end{abstract}

Key words: Class, working class, higher education, social mobility

Please cite this article as:

Hurst, A. (2010). Schoolcraft vs. Becoming Somebody: Competing Visions of Higher Education among Working-Class College Students. Qualitative Studies, 1(2): 75-90.

\section{Introduction ${ }^{1}$}

"Raise your aspirations," [they] said. Educators especially. They love that word. ASPIRATIONS. All over the state you can hear that long word rolling off their tongues. It's something the lowincome people don't have enough of, they say...doesn't he realize that the higher the white-shirt pastel-people raise their aspirations for us who are already failing their idea of success, the more we lose sight of our own true aspirations and the deeper into complete failure they leave us ... "Lowincome people have got to escape," they say. Escape what?" Do they mean leave home? Leave town? Like they did? Do they mean escape that life we have here in Maine with out family ties and hometown ties and go to...to...Harvard or Yale, like they did? Live in a faraway city? Be a yuppie? Is that the only acceptable choice? Why was it so easy for them to leave their homes, these leaders, these experts, these professionals? Were their homes dysfunctional in a way social workers aren't trained to recognize?" - Carolyn Chute

Carolyn Chute, a novelist from the working class, tells this story of herself at a cocktail party. When a professional disparages his workers as "just a pair of hands" she reminisces about working at a poultry plant, and thinks about how workers are disparaged for their lack of ambition, as measured by educational attainment. College students from the working class are engaged in a process of social mobility, or at least so say the experts. In today's economy, a college degree has become indispensable. Study after study shows the great differences in lifetime earnings between those who go to college and those who do not. According to the US Department of Education (1999), 25-

\footnotetext{
${ }^{1}$ This article is part of a longer project studying the experiences and identity reconstructions of working-class college students. For a more detailed discussion of those issues generally, please see The Burden of Academic Success: Loyalists, Renegades and Double Agents (2010). The argument developed here, however, is specific to this publication.
} 
to 34-year-olds who dropped out of high school in 1999 earned an average yearly income of less than $\$ 18,000$. High school graduates earned an average of about $\$ 25,000$. College graduates with a bachelor's or higher degree earned an average of $\$ 40,000$. Over a lifetime these differences can add up to hundreds of thousands of dollars. At the same time, college is often a psychic minefield for working-class college students, who experience college as alienating (Zandy 1995), psychologically stressful and isolating (Hoggart 1957), and at odds with some core working-class values such as cooperation, "making do," and equity (MacLeod 1995: Steinitz \& Solomon 1986; Weis 1985). Some students may even see attending college as a form of betrayal (Clancy 1997). Success in college, after all, is premised upon individual achievement in what is an increasingly competitive culture (Sacks 2007). One person's academic success does nothing for the greater community from which he or she was born, and more often than not can serve to reinforce ideas that those who are poor have only themselves to blame ("if she made it, why can't they?").

This article addresses the meanings of college and academic achievement for a small but diverse group of working-class college students. Why, we may ask, have these students chosen to go to college? Surprisingly, many do not believe that college will "pay off" in an economic sense. They have known too many people who are carrying too much student debt, or who have failed to find good-paying jobs upon graduation, to be completely convinced that a college degree will be financially rewarding in the long run. Many of these students have friends and family members who are in good-paying working-class jobs. Given the time that college takes, especially if one is working full-time while attending classes, many do not believe they will ever catch up to peers who began their working-class jobs out of high school.

But many of these students are also, curiously at first glance, without ambition. Struggling to get themselves to college in the first place, a huge achievement on many grounds, these students then eschew social mobility. Like Carolyn Chute, they retain a powerful sense of "us versus them" and have no desire to trade in their working-class identity for a middle-class career. They are in college because they enjoy it. Or, because they recognize that college is now a necessity even to keep even. Others, in contrast, expect college to be a place where they learn to "access" middle-class norms, behaviors, and resources. They have little interest for the educative side of college, seeing it as a ruse or "hurdle" through which they must jump if they are to gain entry into the ranks of the successful. Such radically different views of college, what it is for, and what can be gained from it, are highly instructive. Amidst ongoing debates about the importance of college, declining access for the masses, and the necessity of a strongly educated workforce (Attewell \& Lavin 2007, Sacks 2007) listening to the stories of those who are on the frontlines can give us a different picture of where college is failing us. I argue that college is failing us because it is too implicated in the class system, and this role as gatekeeper to the middle class is having perverse effects on its educative role.

Furthermore, encouraging everyone to go to college and then blaming those who do not do so, erects a massive charade. Our alleged meritocracy, based upon class-biased measures of academic ability and achievement, separates the winners and losers largely on grounds that parallel class distinctions. Many working-class students are aware of this, some more consciously than others. They thus oppose the dominant framing of themselves as more intelligent than their working-class peers, instead highlighting the role luck played in their educational paths. We also need to remember that college cannot by itself be a cure for class inequality. If everyone did get a college degree, we would still have the same amount of working-class and middle-class jobs. Holding 
college out as the primary (or even exclusive) pathway to a better life undercuts serious attention to alternative collective-based forms of improving working-class jobs. Social mobility is certainly a large component of college participation today, but it is not the only or even most important part for many working-class students.

What literature on working-class college students exists is of two kinds. First, there is a growing body of research and autobiography that indicates the difficulties (alienation, isolation, disparagement) that working-class students face in what is a predominantly middle-class culture (Dews \& Law, 1995; hooks, 1993, 1994; Lubrano 2004; Mahony \& Zmrocek, 1997; Muzzatti \& Samarco, 2006; Ryan \& Sackrey, 1984; Tokarczyk \& Fay, 1993; Villanueva, 1993; Welsch, 2005). Second, researchers have focused on issues of access and aspirations, assuming for the most part that college is a key instrument of social mobility (Attewell \& Lavin, 2007; Avery et al., 2003; Bowen et al., 2005; Golden, 2006; Kahlenberg, 2004; Heller 2002; St. John, 2003). There is something of a Dr. Jekyll \& Mr. Hyde element to these two sets of literature - the first highlighting very problematic issues students from the working class face in college and the second assuming that college is an unmitigated, culturally neutral, benefit. This article attempts to combine the two by exploring the meanings of college attainment as described by working-class college students themselves.

The stories presented here were taken from a phenomenological study theoretically based upon the notion that class cultures exist and have bearing on how people understand and make sense of their current and projected class positions. ${ }^{2}$ I conducted an ethnographic study of twenty-one workingclass college students at a large, moderately-selective public university between 2003 and 2005. The sample was a non-representative snowball sample. I attempted to find students who were quite different from each other so the sample was diverse as to age, race, gender, and general experiences. I was primarily interested in how their class identities were being constructed or reconstructed in the process of becoming college-educated. All of the students interviewed for this study were academically successful students with expectations of graduation and high hopes based upon what that might mean to their economic futures. In addition to substantial interviews, ranging from two to four hours (frequently in multiple sessions), I participated in the same campus culture as the students, albeit from a different position as a graduate student. I sat in on many classes and watched students at work. I also attempted to follow up with the students as they graduated, as I was interested in what would happen to them after college. I received some emails but did not receive enough responses to report on this reliably, although I did one extensive postcollege interview, excerpts of which are included here. Following all the students after college will have to await future study.

\footnotetext{
${ }^{2}$ Because I was primarily interested in the meanings that these students ascribed to both their educations and their class identities (and how these two intertwined) it was appropriate to approach the question qualitatively. Qualitative methods can "illuminate the meanings people attach to their words and actions in a way not possible with other methodologies" (Lareau, 2003, p. 219). I am here not interested in the frequency of behavior but in the meaning of behavior (Lareau \& Schultz, 1996, p. 4). This approach can also be described as phenomenological, in that it "is concerned to provide insight into how, through the human situation, phenomena come to have personal meaning, a lived-through significance that may not always be transparent to consciousness. The focus is upon involvement in a natural-cultural-historical milieu within which individuals discover themselves as subject to meaning. This tradition stresses that we can only understand human phenomena, such as language, in practice, or use" (Charlesworth, 2000, p..3).
} 
In the course of my research I discovered that working-class college students were not all alike. Although all similarly recognized a difference between themselves and their middle-class peers in regards to resources, attitudes, and cultural capital, they differed substantially in the meanings they ascribed to their educational trajectory. Keeping in mind the accounts of working-class academics in which ambivalence towards social mobility was highly developed, I began to classify the students according to the way they chose to navigate between the cultures of the working and middle class. Some, whom I identified as "Loyalists," were committed to retaining a strong working-class identity. Others, whom I identified as "Renegades" were equally committed to disposing of their working-class identity in favor of "accessing the middle class," as one of the students described it. I chose these terms because they neither expressed approval nor disapproval. Loyalists and Renegades are always evaluated differently based on the relationship of the evaluator to the groups in question. A member of an original culture will esteem a Loyalist whereas a member of an adopted culture will similarly esteem a Renegade. ${ }^{3}$

Loyalists and Renegades are not types, but rather examples of strategic orientations. Loyalists' identification with the working class is a strategy that helps them navigate between home and school cultures, just as Renegades' identification with the middle class provides the conceptual meaning for going to college. These strategic orientations played a role in how working-class college students understood the role of higher education and the connection between college and social mobility. Loyalists, loath to leave friends and family behind, were aware that a college degree was necessary to get a good job. They were also aware that they were "good at school," the way others were "good at mechanical work" or "good at construction." College meant access to betterpaying and more secure jobs that would make use of these special academic skills. Loyalists thus saw themselves as "academic craftsmen (and women)."

Renegades, on the other hand, did not see academic work as another craft but as something quite different and superior, and were much less likely to talk about the economic value of a college degree. The primary reason Renegades gave for going to college was to "prove" themselves a worthy person (to family, to society, to self). College was seen as a pathway to the middle class, where being middle class was perceived as being a "normal American."

Strategic orientation also affected responses to the question of whether college is meant for (or good for) everyone. Loyalists didn't think it was and that was just fine. In fact, many Loyalists expressed a preference for an idealized academy. They fervently wanted college to be more meritocratic and less tied with one's economic position. In other words, they believed that going to college should be for those who loved learning and should have nothing to do with one's class position. In this world, mechanics and academics would be equally respected and rewarded. Thus, going to school would

\footnotetext{
${ }^{3}$ I also discovered a third group, whom I designated "Double Agents." These were charismatic students whose desire and ability to move comfortably between social groups marked them as conceptually distinct, although each Double Agent was more or less working-class- or middle-class-identified. Because of this identification, in the interests of space, I will not include findings on this group here. They are developed more fully in my The Burden of Academic Success: Loyalists, Renegades, and Double Agents (2010).

${ }^{4}$ We can see a parallel here with the distinction between the "deserving" and "undeserving poor," first discussed by Gans (1990).
} 
in no way raise status (nor would not going to school decrease it). In contrast, Renegades acknowledged that going to college was a normative ideal. In other words, having a degree marked one as a decent person. Without that degree, one was more likely to be seen as "less than", stupid, and lazy. Thus, they were very eager for everyone to go. Nor did they think it was very hard to do so.

Third, strategic orientation affected responses to the question whether having a degree would make one "middle class." Loyalists did not believe it would while Renegades very fervently did. In a related manner, Loyalists were very adamant that having a college degree would not make them "better" than those without degrees. Just as adamantly, Renegades thought it would.

\section{The Loyalist Vision: Schoolcraft}

Most Loyalists were very honest about their desires to make more money. This, they told me, was the reason they were in college. Helping family out ("The purpose for me to get through school is, I think, by bettering myself I'm able to bring back something to my family, so, my long-term goal is that I want to help my family to find a better positions financially") and overcoming a bad job market ("You need a college degree to get any sort of job. A job that will put you above the poverty line") were the two main stories told here.

Despite this attention to the "bottom line" and the economy, Loyalists also expressed a true love of school and became visibly excited when discussing their coursework. Criticisms of "careeroriented" college students thus miss an important point - students can be both aware of the importance of a college education for future earnings and be good academics. How is this possible? I believe the answer lies in the particular way that some working-class college students interpret academia as one of many skilled endeavors. For example, Jay, a transfer student from the local community college, made explicit comparisons between his academic work and the work his brother did as a mechanic. Jay was "all thumbs" but enjoyed reading, where his brother was just the opposite. Jay was a skilled craftsperson like his brother, but his craft was schoolcraft.

It must not be forgotten that going to college is a very big exception for the average working-class child. These students had excelled most of their lives, and were doing quite well at the time of the interviews. Most of them expected others to feel the same way they did about education and were disappointed to find so many students who seemed to take no interest in their studies (or pride in their craft). They were chagrined that so many more privileged students seemed to be simply "treading water," uninterested in what was actually being taught. They often ascribed this to the fact that more privileged students did not have to work so hard to get to college in the first place. They were impatient with students who spent their college years "partying" rather than getting the most out of their coursework.

Loyalists did not want college to be a "party place" and social rite of passage for young adults. Instead, they invariably described an ideal academic setting that would be truly challenging and only available to those who really desired it. To make this work, of course, college had to be completely delinked from the economy. College would ideally be free and available to all, but would not economically reward those who participated. In other words, college should have absolutely nothing to do with one's class position (either coming in or going out). This ideal college is not for everyone - nor should it be: 
"I really do not think it is for everybody... I don't think it's for everyone. I think school of some sort should be accessible to everyone, and I think there is a niche for everyone, just like my friends in technical school or massage school. I think college can be for everyone but four-year college and graduate school, definitely not. At all."

Again, Loyalists recognize schoolcraft as one of many alternative crafts. Thus, college was but one path of many equally valid choices. This meant that Loyalists did not look down on those who chose other paths. Max, a retired trucker completing his bachelor's degree in sociology, had a seventeen-year old son who had dropped out of high school to work on cars. Max was clearly proud of his son's skills in this area:

“My oldest son quit school because he said they were raising mill workers there and he didn't want to be a mill worker. So he quit school. He sees all these people going into the mill around him. What do they do? They push boards around. He doesn't want to do that. Now he actually has a skill, skilled labor I guess? I guess you would classify as? [Q: What does he do?] He builds custom cars [says with pride]. He knows how to cut and stretch, you know, paint, well, he doesn't quite have the painting yet. Spray painting. [Q: Yeah, the painting can get pretty elaborate]. Yeah!"

For similar reasons, Bethany was enraged in class one day when the instructor suggested, "everyone should go to college." I was taken aback by her vehemence and asked her why this statement upset her so much. She recognized that by saying that everyone should go, those who don't go are going to be devalued. She also took offense that this was couched in moralistic terms (which is an interesting contrast to how Renegades understand school, as will be discussed below). Although Bethany enjoyed academic work, she was sure that this was not the case for everyone. She was also quite critical of the fact that college tended to teach the values of the middle class, and in particular stressed skills useful for management. I don't believe Bethany had clearly sorted out her critiques at this point (who has at the age of twenty-one?), but her emotional responses were nevertheless quite clear.

Loyalists did not believe that having a degree would make them "middle class. Most of them appeared to be using a cultural definition of middle class when answering this question. That is, they stressed the permanence of working-class affinities and loyalties even in the face of occupational mobility ("I will always be, I don't know if my class will be working class, but I will always be a working-class person, you know? Like my morals and my experiences and I will always think that people who dry their laundry in the summer are wasting energy. And money."). A few also pointed out, however, that having a degree would not guarantee them a middle-class job, either. They hoped that they would at least be economically secure - "I would like to see myself not have to stress over the lack of resources and even further to perhaps use my resources to help people that I care about but no, I won't be middle class! Yeah, that's it, I don't think anyone wants to be poor." Many were also confused about the question, "I think when I moved here with my family I was living a middle-class lifestyle but I never actually felt it, does that make sense? Now I am in that spot, now I don't know what to call myself. I am, I have an education, and I want to continue with it, but I really don't know how to classify myself." 
Loyalists were often quite clear about not wanting to become middle class if that meant taking on an occupational role that would be antagonistic to the working class. Anti-boss statements were often expressed vehemently. It was clear that, unlike the general question about class position for which many students were unsurprisingly ill-prepared, these students had given serious thought to what it meant to be a boss or a worker, and where they stood and wanted to stand in the economic hierarchy. Jay, a White man in his late 20s who considers himself a Marxist, had very negative stereotypes of the middle class, often derived from his years working as a HVAC installer. Given these negative feelings, his ambitions in some directions have become blunted, "knowing how I feel about capitalists there was nothing there for me to work towards." Interestingly enough, he believed he would more likely be a professional if the working class were not devalued. In other words, choosing a middle-class occupation or lifestyle was morally wrong to Jay, a working-class Loyalist. No position alone would sway him from his allegiances. He told me he "didn't buy" the theory that having a college degree made one middle class,

"Even if I were to get a professional job -- I think the difference between doing a job and feeling a job, I think there's a difference there. And if I were working in an office and I saw the boys come through who were out working on houses I think I would feel guilty. Guilty that I wasn't out there working. Making the money. Doing the work. Yeah, I do have a hard time trying to figure out what class is. I'm not sure there is or isn't one, the working-class, but I know there are people out there who break their backs to do the work so other people don't have to."

Like Jay, Calder would refuse to accept certain occupational positions based on his class loyalties. Thus, he hoped to make a decent salary (one that some might call middle-class) but he categorically refuses to become a "professional/managerial person." These people have interests oppositional to those of his people. They require the "loss of heart" - "You have to kind of have a cold heart to do that and I want to be the type of person that doesn't judge anybody, if they know who they are, and I respect people, and I don't wanna be no arrogant type person. Or a mean person! Or anything! And so it would be hard for me to take a job where I was making a lot of money. Because I don't see money as, it's just paper!"

Loyalists were also in agreement that having a college degree did not make you "better" than those without one. This is in keeping with their responses to the question of whether college is for everyone. They were quite adamant about this point and gave several examples of friends and family members who did not go on to college but were "smarter," "more talented," or "better people." Or, as Calder points out, perhaps just more fun to be around:

“I don't see a certificate automatically making someone anything...So you can hold up your degree and you shouldn't be knocked for it, but it doesn't mean that you are better than the guy holding the shovel over there. I mean, no way. Because that guy over there he is probably a lot more funnier, and better to be around then you!"

Bethany, who remembered watching her father go out on strike with his union, admitted that she used to believe you were "weak" if you didn't go on to college. By the time I interviewed her she had changed her mind. She was acutely aware of class oppositions, and, as discussed above, understood that college prepared students for managerial and supervisory jobs. When asked if she would take such a job at her father's company her response was immediate - "Oh my God. I 
couldn't do it. No, no way. I couldn't...My dad would feel so betrayed. He really would. Yeah. It would never be about the money...like, I couldn't work for [name of major MNC]. There are some corporations that I couldn't work for having nothing to do with my dad."

In summary, Loyalists tend to see college as necessary for economic security, especially given the state of the job market. They would prefer that this was not the case, however. In a perfect world, college would be free and open to anyone, but only those who were academically inclined would go. They would not be rewarded any more for this than any other skilled laborer. Although Loyalists may hope that college improves their class position, they do not want college to change their working-class identification. ${ }^{5}$ Finally, Loyalists do not believe that having a college degree makes you any better than someone without one.

\section{The Renegade Vision: You're Nobody without a College Degree}

Students employing Renegade strategies appreciated college in a much different way. For these students, going to college was a way of proving their worth, not just intellectually or economically but morally as well. College was pursued to dispel class stereotypes of ignorance and laziness, to remove social stigmas, and to heal class wounds, ("I kind of pride myself on that kind of stuff because I feel like I am always looking to break the stereotype.") Academic success for workingclass children does break a very powerful social stereotype that sees the working class as ignorant, stupid, lazy, and morally inferior. Renegades like Bob, a White man in his late 20s and son of a millworker, are acutely aware of this stereotype:

"It is the level. It's not the work. You know, it's the level that you are perceived at doing that work, not the work... Yeah, even your perceived intelligence level. You know, if you said you worked at Safeway as a checker, and then you said you were a grad student, people are going to perceive you differently. Maybe to me part of my identity is how other people perceive me, I think it is to everybody, and I think it's just, you know different. Society looks at people who pump gas and that work in grocery stores and that work in mills as people with no ambition and people who have nothing, not people who are smart but just people who are doing a job. They look at people like lawyers and doctors and actors and baseball players as people with an exceptional skill or ability that should be put above the rest."

Sometimes these class stereotypes are also racialized. About half of the Chicano/a students I interviewed were using college as a way to escape both class and racial shame and humiliation. John, for example, carried an identity as "the darkest-skinned" of all of his parent's children. He felt stigmatized as a child by his mother, who, he believed, treated him as "less than" his siblings. Doing well in school was his way of showing his mother that he mattered - that he was not just the equal, but the superior, of her other (lighter-skinned) children.

Renegades believed that everyone should go to college. By failing to do so, one remains marked as socially inferior. To a large extent, Renegades believed, this was entirely one's own fault ("Everyone should go - it isn't that hard. If you don't go, it's your own fault.) All that it took was the will and the desire; or, more accurately, the belief that a different future was possible. It was thus imperative

\footnotetext{
${ }^{5}$ As reported by many working-class academics, it is quite possible to have a middle-class occupational position and retain a working-class-identification.
} 
to reach working-class children at an early age and instill the desire in them to go on to college. Many Renegades took this as a personal mission of theirs. And they primarily blamed workingclass parents for failing to instill this desire,

“The thing that is the key, I've seen it in working-class schools, it's huge, because you can tell which kids think or have parents who think that school is the key. And that it is a great place. And then you can tell the kids who have parents who they go home every night and they say, whatever, school's stupid. So the people who had successes in school are going to breed people who have success in school I think."

Nor do Renegades believe college is that difficult. Their discussions of college hardly ever focus on academics. College is a hoop through which to jump, coming out on the other side as a validated person. Unlike Loyalists who stress the educational process, Renegades stress the social side of college, college as a classed terrain. Bob had one of the most complete analyses of this. Bob was the one student who I was able to interview after his degree completion, when his failure to get a middle-class job was causing him to reconsider a lot of his earlier assumptions about college and his own identity. He argued that social networking was really the key to social mobility, "If I would have done it again, I would have met a bunch of rich people, and I would have made them all my buddies." Bob saw the classing nature of college first and foremost - "I don't think college is about learning. I think college is about money. I think when it comes right down to it this is a business. This place makes a ton of money and I know that the upper class people need it to keep their people upper class so the more they can charge and the more they can make the better it is for all of them." On the other hand, "even if you come out of college and you don't do well I would still say, anyone should go to college. And not just for the education. Because it changes you."

While both Loyalists and Renegades saw the classed nature of college they reacted to it differently. Where Loyalists advocated a radical decoupling of education and the class system, Renegades, perhaps more realistically, tried to take advantage of college as a mechanism of social mobility. As a result, Renegades did believe that earning a college degree would make them middle class. This is the promise that education has always held out to them. They believe they are thereby leaving the working class behind - "The class I'm in, of course I totally think I'm leaving it." Rather than focus on jobs or work, Renegades focused on the acquisition of certain cultural skills. Thus, for Talia, a young White woman who was periodically homeless during her 20s, having a drive to succeed distinguished her from the rest of the working class, although she also acknowledged that middleclass patterns of behavior didn't come naturally to her:

"On the basis of goals [I am middle class]. This is what I'm doing right now, but these are the places I am moving on to - my goals and my dreams and my future - versus a person in a lower class who is like "oh, I got 50 extra bucks, what should I do with it? Let's go spend it on this that and the other thing." It's very much a here and now, you can't see past type of mentality that I feel like I guess now that you ask me is a big difference between classes. So, on that basis I would definitely say I'm a middle-classer, definitely not a serf. But I guess innately when I'm around people and families that are middle class or upper class I don't necessarily feel like I fit in. I feel like I have to work at it a little bit. Because I have to remember to have certain manners." 
Renegades were not driven by avarice or selfishness. Many Renegades made very real sacrifices in order to prove themselves worthy in a class-conscious society. These sacrifices (of family, relationships, time, happiness, and in some cases families of their own) were undertaken with the expectation that they will come out on the other side, in a better place, and with more respect. John, for example, pointed out the importance of having a degree even if he eventually decided to follow his dream of being a boxer, "[College] is something that I can always fall back on. No one can ever take that degree away from me. No one can ever take away what I've learned. And it's something to put down on your resume. You know? But if I had just gone straight to boxing, people probably would have said, 'that kid never even went to school'."

Because they see academic success, social mobility, and moral wealth as tied up together (much as the greater society does), Renegades do feel that they are better than those who did not make these sacrifices. This can further separate Renegades from their families, as Isabel points out - "I guess college has made me a better person -- not one that my family necessarily likes because it is not the one that they grew up with. But I like it, I love it."

The Renegades' arguably more realistic understanding of the costs and payouts of college is more in tune with societal understandings of social mobility through education, but this does not necessarily mean that they will succeed. Having access to fewer material resources than their peers, less national social networks and often insufficient social capital, and having to acquire middle class cultural capital later in life than their peers, accessing the middle class is not quite as easy as getting a college diploma (which in itself is not easy at all). Whereas I worried that Loyalists would not take full advantage of the opportunities college affords them for fear of "selling out," I feared that Renegades would be disillusioned after college if they were not afforded all the opportunities they clearly expected. Bob, the son of a millworker, was bitter and humiliated after college when he could not find a job that was commensurate with his education. He ended up using the only social networks he knew, that of his family, and found a job at the mill, earning less money, of course, than his friends and family who had started there right out of high school. Having internalized many class stereotypes, he was having a hard time dealing with the fact that he was now working an industrial job. College taught him he was "better" than the jobs he now holds:

“The first job I was offered out of here was for $\$ 45,000$ a year but it was a blue-collar job and college had taught me that I was above that...I didn't go to college to unload laundry and floor mats! I don't want this job. Six months later I can't find a job. And I go to HS Industries ${ }^{6}$ making $\$ 9.50$ an hour. I thought I was above that, I did. That's ego right there, that's stupidity...It was just that I thought I should get out of college and wear a suit and tie to work. I didn't go to college to do this. Coming out of college, I wanted to be able to go home and say look at what I'm doing now. Look at what I have achieved. I have accomplished something."

\section{Conclusion}

The preceding accounts convey the complexity of "going to college" for students from the working class. College can mean many contradictory things, including becoming a "better" (i.e., morally superior) person, getting credentialed, learning to be a good citizen, experiencing diversity, and becoming middle class. It can also be an alternative to unemployment or the military. Underlying

${ }^{6}$ This, and all names of employers, have been changed for the sake of anonymity. 
these accounts is a subtle critique of college's social mobility function, a nascent awareness that something is wrong with the American fixation on "getting ahead" through education. This is as true for Loyalists who reject assimilation into the middle class as it is for Renegades who see college as just another hurdle designed to keep them from achieving parity with children born into privileged families. What is so often lost in discussions of expanding access to college is the question, what is college for? Is it truly meant to educate everyone to be better citizens and active participants in democracy? Or is it a "stamp of approval" on those who participate certifying them as acceptable for positions of management and supervision?

A basic problem that many working-class college students will face upon graduation is the surprise attendant on not finding the type of job they expected to get (Fraser 2001; Smith and Powell 1990), or finding that available jobs do not pay enough to repay student loan debt (Fossey \& Bateman 1998; Kamenetz 2006). As discussed earlier, in our current economy, having a college degree does not ensure secure employment (Archer \& Hutchings 2000; Bowen et al. 2009; Taub 2006; Volkwein \& Cabrera 1998). College degrees actually "pay off" less for people of color, women, and the working class (Sacks 2007; Smart \& Pascarella 1986; Walpole 2007). 7 But a more basic question might be, for what future exactly are colleges preparing students? If colleges prepare students only for the twenty percent or so of "middle-class" professional-managerial positions that our occupational system holds, how can we seriously advocate college for all? If college is to have meaning for the working class beyond those who want to access those key positions of power, the meaning and content of higher education must change.

Certainly most colleges do a poor job teaching agency, collective action, and other issues pertinent to our growing working class. Working-class students must be encouraged and assisted in reclaiming their agency. Colleges should inculcate an understanding and appreciation of collective agency (Loeb, 1994, p. 65). This can be achieved by discussing the role of unions and class-based social movements in American society and by decreasing the use of the "great leader" approach to history that is so common in our educational practices. College curricula should include workingclass histories, perspectives, and realities. This might allow working-class students to feel a deeper connection to higher education, and might also allow them to draw links between what they learn in school and what they do and who they are in their home communities.

All of this would go a long way towards creating organic intellectuals among the working class, rather than "unattached individuals" (Apple 1979, p. 166). College does play a role in constructing and reconstructing class identities and allegiances. It need not continue to suppress working-class identities and loyalties. We must challenge the assumption that we educate people so that they can enter the middle class (Cappello, 1995, p. 132). The implicit acculturation model adopted by colleges is exactly the wrong approach. In his work with working-class Native American students, Tierney (1992, p. 615) writes,

\footnotetext{
7 This may in fact have something to do with social and cultural capital differences, which college may actually exacerbate. Zweigenhaft (1993) found striking differences between the social and cultural capital of students at Harvard who had gone to prep schools versus those who had not. Those who had attended prep school spent much more time accumulating social capital than their peers, and less on academic achievement. This may have contributed to superior occupational outcomes.
} 
"Instead of implying that being 'drawn back' to one's own culture is a shortcoming, one might accentuate that ripping one away from his or her native culture is detrimental and harmful. Rather than think of college as an abrupt transition from one world to another, we might try to conceptualize college life as reinforcing and incorporating what one has learned from one's extended family."

Many working-class students do not foresee the inevitable conflicts "between their values and those of institutions like universities", and thus "they are not prepared to fight for recognition of the legitimacy of their values and their struggle to move up while they maintain their nurturing relationships" (Steinitz \& Solomon, 1986, p. 241). At a minimum, colleges can better prepare students for these "inevitable conflicts."

Our present conceptualization of college as a path of individual "upward" mobility is flawed, biased, and harmful to the working class. To the extent that we force schools and colleges to play a major role in classifying people through educational credentials, we lose sight of the true values of education. The point of going to college cannot be restricted to allowing some (fortunate) individuals to pass over/into the other side. Education in a democratic society should be about preparing people for full and active participation in civic life (Bowles \& Gintis, 1976, p. 250); in a class-based society this would include preparing students to become leaders of their working-class communities (in the same way that college now prepares middle-class students to become leaders of their communities). Paulo Freire's work is instructive here. He "was not interested in helping border crossers make it over safely. He was interested in helping the poor recognize the social and economic interests that bind them together as a group, to take strength from their group identity and begin to struggle to further their interests through democratic means, and to recognize that they confront, not individuals outside their group, but other groups whose interests are often antagonistic to theirs" (Finn, 1999, p. 172).

Making and examining links between past, present, and future, is imperative. Too often workingclass students are expected to leave their pasts at the door. Colleges must help these students understand and make use of their pasts in their present and future lives. After all, this may be our best hope for a true democracy of the future. This is a question of more than access, but of justice.

\section{References}

Adair, Vivyan C. \& Sandra L. Dahlberg. 2003. Reclaiming Class: Women, Poverty, and the Promise of Higher Education in America. Philadelphia: Temple University Press.

Apple, Michael W. 1979. Ideology and Curriculum. Boston: Routledge \& Kegan Paul.

Archer. Louise and Merryn Hutchings. 2000. "Bettering Yourself” Discourses of Risk, Cost and Benefit in Ethnically Diverse, Young Working-Class Non-Participants' Constructions of Higher Education." British Journal of Sociology of Education 21:4, 555-574.

Attewell, Paul A. \& David E. Lavin. 2007. Passing the Torch: Does Higher Education for the Disadvantaged Pay Off across the Generations? New York: Russell Sage Foundation. 
Avery, Christopher, Andrew Fairbanks and Richard Zeckhauser 2003. The Early Admission Game: Joining the Elite. Cambridge: Harvard University Press.

Berkner, Lutz and Susan Choy. 2008. Descriptive Summary of 2003-2004 Beginning Postsecondary Students: Three Years Later. Washington, DC: US Department of Education.

Bowen, William G., Martin A. Kurzweil and Eugene M. Tobin 2005. Equity and Excellence in American Higher Education. Charlottesville: University of Virginia Press.

Bowen, William G., Matthew M. Chingos and Michael S. McPherson. 2009. Crossing the Finish Line: Completing College at America's Public Universities. Princeton: Princeton University Press.

Bowles, Samuel \& Herbert Gintis 1976. Schooling in Capitalist America: Educational Reforms and the Contradictions of Economic Life. New York: Basic Books.

Cappello, Mary 1995. "Useful Knowledge," in This Fine Place So Far From Home, edited by C.L.B. Dews and Carolyn Leste Law. Philadelphia: Temple University Press: 127-36.

Charlesworth, Simon J. 2000. A Phenomenology of Working Class Experience. Cambridge: Cambridge University Press.

Clancy, Kim. 1997. “Academic as Anarchist: Working-Class Lives into Middle-Class Culture.” in Class Matters: Working-Class Women's Perspectives on Social Class, edited by Pat Mahony and Chritine Zmroczek. London: Taylor \& Francis

Dews, C.L. Barney and Carolyn Leste Law. 1995. This Fine Place So Far From Home: Voices of Academics from the Working Class. Philadelphia: Temple University Press.

Draut. Tamara. 2006. Strapped: Why America's 20s and 30s-somethings Can't Get Ahead. New York: Doubleday.

Finn, Patrick J. 1999. Literacy with an Attitude: Educating Working-Class Children in Their Own SelfInterest. Albany, NY: State University of New York Press.

Fossey, R. and M. Bateman 1998. Condemning Students to Debt: College Loans and Public Policy. New York: Teachers College Press.

Fraser, Jill Andresky. 2001. The White-Collar Sweatshop: The Deterioration of Work and Its Rewards in Corporate America. New York: W.W. Norton.

Gans, Herbert. 1990. The Undeserving Poor: From the War on Poverty to the War on Welfare. New York: Pantheon.

Golden, Daniel 2006. The Price of Admission: How America's Ruling Class Buys Its Way into Elite Colleges - and Who Gets Left Outside the Gates. New York: Crown Publishers. 
Heller, Donald E. 2002. Condition of Access: Higher Education for Lower-Income Students. Westport, CT: Praeger.

Hoggart, Richard 1957. The Uses of Literacy: Changing Patterns in English Mass Culture. Fair Lawn, NJ: Essential Books.

hooks, bell 1993. "Keeping Close to Home: Class and Education" in Working-Class Women in the Academy, edited by M.M. Tokarczyk \& E.A. Fay. Amherst, MA: University of Massachusetts Press.

Hurst, Allison. 2010. The Burden of Academic Success: Loyalists, Renegades, and Double Agents. Lanham, MD: Lexington.

Hurst, Allison. 2007. “Telling Takes of Oppression \& Dysfunction: Narratives of Class Identity Reformation." Qualitative Sociology Review 3:2, 82-104.

Kahlenberg, Richard D., ed. 2004. America's Untapped Resource: Low-Income Students in Higher Education. New York: Century Foundation Press.

Kamenetz, Anya. 2006. Generation Debt. New York: Riverhead Books.

Lareau, Annette 2003. Unequal Childhoods: Class, Race, and Family Life. Berkeley: University of California Press.

Lareau, Annette and Jeffrey J. Shultz 1996. Journeys through Ethnography: Realistic Accounts of Fieldwork. Boulder: Westview Press.

Loeb, Paul Rogat 1994. Generation at the Crossroads: Apathy and Action on the American Campus. New Brunswick, NJ: Rutgers University Press.

Lubrano, Alfred 2004. Limbo: Blue-Collar Roots, White-Collar Dreams. Hoboken, NJ: John Wiley \& Sons.

MacLeod, Jay 1995. Ain't No Makin' It: Aspirations and Attainment in a Low-Income Neighborhood. Boulder: Westview Press.

Mahony, Pat and Christine Zmroczek 1997. Class Matters: Working-Class Women's Perspectives on Social Class. London: Taylor \& Francis.

Muzzatti, Stephen L. and C. Vincent Samarco 2006. Reflections from the Wrong side of the Tracks: Class, Identity, and the Working Class Experience in Academe. Lanham: Rowman \& Littlefield.

Ryan, Jake \& Charles Sackrey 1984. Strangers in Paradise: Academics from the Working Class. Boston: South End Press.

Sacks, Peter 2007. Tearing Down the Gates: The Class Divide in American Education. Berkeley: University of California Press. 
Smart, John C. and Ernest T. Pascarella. 1986. "Socioeconomic Achievements of Former College Students." The Journal of Higher Education 57:5, 529-549.

Smith, Herbert L. and Brian Powell. 1990. “Great Expectations: Variations in Income Expectations Among College Seniors." Sociology of Education: 63:3. 194-207.

St. John, Edward P. 2003. Refinancing the College Dream: Access, Opportunity, and Justice for Taxpayers. Baltimore: Johns Hopkins University Press.

Steinitz, Victoria Anne and Ellen Rachel Solomon. 1989. Starting Out: Class and Community in the Lives of Working-Class Youth. Philadelphia: Temple University Press.

Tierney, W.G. 1992. "An Anthropological Analysis of Student Participation in College." The Journal of Higher Education 63:5, 603-18.

Tokarczyk, Michelle M. \& Elizabeth A. Fay 1993. Working-Class Women in the Academy: Laborers in the Knowledge Factory. Amherst, MA: University of Massachusetts Press.

US Department of Education 1999. Getting Ready for College: A Report for National College Week. Washington, DC: US Government Printing Office.

Villanueva, Victor 1993. Bootstraps: From an American Academic of Color. Urbana, Ill: National Council of Teachers of English.

Volkwein J.F. \& A. F. Cabrera 1998. “Who Defaults on Student Loans? The Effects of Race, Class, and Gender on Borrower Behavior," in Condemning Students to Debt, edited by R. Fossey. New York: Columbia University Press.

Walpole, Marybeth. 2007. Economically and Educationally Challenged Students in Higher Education: Access to Outcomes. San Francisco: Jossey-Bass.

Weis, Lois. 1985. Between Two Worlds: Black Students in an Urban Community College. Boston: Routledge \& Kegan Paul.

Welsch, Kathleen 2005. Those Winter Sundays: Female Academics and Their Working-Class Parents. Lanham, MD: University Press of America.

Zandy, Janet 1995. Liberating Memory: Our Work and Our Working-Class Consciousness. New Brunswick, NJ: Rutgers University Press.

Zweigenhaft, Richard L. 1993. "Prep School and Public School Graduates of Harvard: A Longitudinal Study of the Accumulation of Social and Cultural Capital." The Journal of Higher Education. 64:2, 211-225. 
Qualitative Studies, 1(2)

\section{Author}

Allison L. Hurst is Assistant Professor of Sociology at Furman University, SC, USA. Trained as both a lawyer and sociologist, she is interested in issues of class inequality and class consciousness. She is currently researching the impact of student debt on college students' lives and opportunities for mobility. Email: allison.hurst@furman.edu 